\title{
Ligularia fischeri inhibits endothelial cell proliferation, invasion and tube formation through the inactivation of mitogenic signaling pathways and regulation of vascular endothelial cadherin distribution and matrix metalloproteinase expression
}

\author{
JAE HYEON KIM ${ }^{1 *}$, HYEON-JU KIM ${ }^{1 *}$, JIN-KYU KIM ${ }^{2}$, EUN-KYUNG AHN ${ }^{2}$, HYE-JIN KO ${ }^{2}$, \\ YOUNG-RAK CHO ${ }^{2}$, SANG-JIN LEE ${ }^{3}$, GYU-UN BAE ${ }^{3}$, YONG KEE KIM ${ }^{3}$, \\ JONG WOO PARK ${ }^{4}$, JOA SUB OH ${ }^{1,2}$ and DONG-WAN SEO ${ }^{1}$ \\ ${ }^{1}$ College of Pharmacy, Dankook University, Cheonan 330-714; ${ }^{2}$ Natural Products Research Institute, Gyeonggi Institute \\ of Science and Technology Promotion, Suwon 443-270; ${ }^{3}$ Research Center for Cell Fate Control, \\ College of Pharmacy, Sookmyung Women's University, Seoul 140-742; ${ }^{4}$ School of Pharmacy, \\ Sungkyunkwan University, Suwon 440-746, Republic of Korea
}

Received February 2, 2015; Accepted May 4, 2015

DOI: $10.3892 /$ or. 2015.4000

\begin{abstract}
Ligularia fischeri (LF) has been used as an edible herb and traditional medicine for the treatment of inflammatory and infectious diseases. In the present study, we report the effects and molecular mechanism of the ethanolic extract of LF on cell proliferation, invasion and tube formation in human umbilical vein endothelial cells (HUVECs). LF-mediated inhibition of cell proliferation was accompanied by reduced expression of cell cycle-related proteins such as cyclin-dependent kinases (Cdks) and cyclins, leading to $\mathrm{pRb}$ hypophosphorylation and $\mathrm{G}_{1}$ phase cell cycle arrest. We also show that LF treatment inhibited cell invasion and tube formation in HUVECs. These anti-angiogenic activities of LF were associated with the inactivation of mitogenic signaling pathways, induction of vascular endothelial (VE)-cadherin distribution at cell-cell contacts and inhibition of matrix metalloproteinase (MMP) expression. Collectively, our findings demonstrate the pharmacological functions and molecular mechanisms of LF in regulating endothelial cell fates, and support further development as a potential therapeutic agent
\end{abstract}

Correspondence to: Professor Dong-Wan Seo, Department of Pharmacy, College of Pharmacy, Dankook University, 119 Dandae-ro, Cheonan 330-714, Republic of Korea

E-mail: dwseomb@dankook.ac.kr

${ }^{*}$ Contributed equally

Key words: vascular endothelial cadherin, Ligularia fischeri, angiogenesis, human umbilical vein endothelial cell, matrix metalloproteinase for the treatment and prevention of angiogenesis-related disorders including cancer.

\section{Introduction}

Angiogenesis, the formation of new blood vessels from pre-existing neighboring vessels, is essential for pathological conditions including cancer, ocular disorders, arthritis and obesity as well as physiological processes such as wound-healing, menstruation and ovulation $(1,2)$. The process of angiogenesis includes endothelial cell proliferation, migration, adhesion, invasion, tube formation and recruitment of pericytes, and is tightly regulated by the complex interplay of angiogenic and anti-angiogenic factors within tissue microenvironment (3-5). Matrix metalloproteinases (MMPs) play important roles in tissue remodeling by degrading extracellular matrix (ECM) components and cell surface molecules, leading to angiogenic responses associated with cancer growth and progression (6-8). MMP-mediated cleavage of vascular endothelial (VE)-cadherin in cell surfaces may promote vascular permeability, proliferation, invasion and capillary-like structure formation by dissociating cadherin-catenin complex and disrupting cell-cell adhesion (9-14). The activities of these MMPs are regulated by endogenous inhibitors, tissue inhibitors of metalloproteinases (TIMPs) (15). In addition to MMP-inhibitory activity, many investigations demonstrate that TIMPs regulate cell fates such as proliferation, migration, apoptosis and differentiation through MMP-independent mechanism (16-21). Molecular mechanisms underlying regulation of expression and activities of MMPs and TIMPs may be attractive therapeutic targets and strategy for intervention in angiogenesis-related disorders including cancer. However, MMP inhibitors in multiple clinical trials show severe musculoskeletal pain and inflammation as well as limited efficacy, 
suggesting that the identification of the specific MMP target is absolutely required for realizing the clinical potential of MMP inhibitors $(22,23)$.

Ligularia fischeri (LF) (Ledebour) Turczaninow var. spiciformis Nakai (Compositae), an edible herb distributed in Eastern Asia including Korea, China and Japan, has been used in traditional medicine to treat rheumatoid arthritis, erysipelas, scarlet fever and jaundice. Previous investigations demonstrate that the extracts and biologically active components of LF exert anti-inflammatory, anti-oxidative, anti-hepatotoxic and anti-obesity activities (24-29). In addition, several studies show the anticancer activity of LF against various cancer cell lines including acute promyelocytic leukemia, oral cancer, breast cancer, lung cancer and ovarian cancer cells (30-33). However, the biological effects of LF on angiogenesis associated with cancer growth and progression have not yet been explored. In the present study, we evaluated the regulatory effects and molecular mechanisms of LF on cell proliferation, invasion and capillary-like structure formation in human umbilical vein endothelial cells (HUVECs).

\section{Materials and methods}

Cell culture conditions. Primary cultures of HUVECs were purchased from Lonza (Walkersville, MD, USA) and used between passages 3 and 6 for all experiments. Cells were cultured in EGM- ${ }^{\circledR}$ BulletKit containing endothelial basal medium-2 (EBM-2) and the following growth supplements (EGM-2 ${ }^{\circledR}$ SingleQuots Kit: human epidermal growth factor, vascular endothelial growth factor, R3-insulin-like growth factor-1, human fibroblast growth factor, ascorbic acid, hydrocortisone, heparin, fetal bovine serum and gentamicin/amphotericin B) (designated as complete media), according to the manufacturer's instructions (Lonza).

Reagents. The following pharmacological agents and antibodies were purchased from commercial sources: anti-phospho-extracellular signal-regulated kinase (ERK) (T202/Y204), anti-phospho-Akt (S473), anti-phospho-p70 ${ }^{\text {S6K }}$ (T421/S424), anti-phospho-p38 ${ }^{\mathrm{MAPK}}$ (T180/Y182), anti-MMP-2, anti-MMP-9, anti-phospho-pRb (S780) and anti-phospho-pRb (S807/S811) (all from Cell Signaling Technology, Beverly, MA, USA); anti-p27 ${ }^{\text {Kip1 }}$ (BD Biosciences, Bedford, MA, USA); anti-ERK, anti-Akt, anti-p70 ${ }^{\mathrm{S} 6 \mathrm{~K}}$, anti-p38 $8^{\mathrm{MAPK}}$, anti-cyclin-dependent kinase (Cdk)4, anti-Cdk2, anti-cyclin D, anti-cyclin E, anti-actin antibodies and mouse and rabbit IgG-horseradish peroxidase conjugates (Santa Cruz Biotechnology, Santa Cruz, CA, USA).

Preparation of LF extract. Five hundred grams of LF were extracted with 2 liters of ethanol and stirring for $5 \mathrm{~h}$. The extract of LF was obtained as previously reported (32).

Cell viability and proliferation assay. Subconfluent HUVECs, plated on 6-well plates ( $1 \times 10^{5}$ cells/well; BD Biosciences), were serum-starved for $14 \mathrm{~h}$ in EBM-2 media to synchronize cells in $G_{1} / G_{0}$ phase of cell cycle and incubated for $24 \mathrm{~h}$ in EGM-2 BulletKit media in the presence or absence of LF ( 1 and $10 \mu \mathrm{g} / \mathrm{ml}$ ). Following culture for $24 \mathrm{~h}$, cell viability was determined by a Muse ${ }^{\mathrm{TM}}$ Cell Analyzer using Cell Count and Viability Assay kit (Merck Millipore, Billerica, MA, USA), and the cell proliferation was quantified as previously described (34). The results from triplicate determinations (mean \pm standard deviation) are presented as the fold-increase of the untreated controls or the percentage of viable cells of the total cell count.

Cell cycle analysis. Quiescent HUVECs were incubated for $24 \mathrm{~h}$ in EGM-2 BulletKit media in the presence or absence of LF $(10 \mu \mathrm{g} / \mathrm{ml})$. Cells were harvested with trypsin-EDTA, rinsed with phosphate-buffered saline (PBS, $\mathrm{pH}$ 7.4) and then fixed with ice-cold $70 \%$ ethanol for $3 \mathrm{~h}$. After washing with PBS, cells were stained with Muse ${ }^{\mathrm{TM}}$ cell cycle reagent. The profile of cells in the $G_{1} / G_{0}, S$ and $G_{2} / M$ phases of the cell cycle was analyzed with a Muse ${ }^{\mathrm{TM}}$ Cell Analyzer (Merck Millipore) (35).

Western blot analysis. Quiescent HUVECs in 100-mm dishes $\left(1 \times 10^{6}\right.$ cells/dish; BD Biosciences) were incubated for $15 \mathrm{~min}$ or $24 \mathrm{~h}$ in EGM-2 Bulletkit media in the presence or absence of LF $(10 \mu \mathrm{g} / \mathrm{ml})$. Cells were rinsed twice with ice-cold PBS and lysed by incubation in $50 \mathrm{mM}$ Tris- $\mathrm{HCl}$ (pH 7.4), $150 \mathrm{mM} \mathrm{NaCl}, 10 \%$ glycerol, $1 \%$ Triton X-100, $1 \mathrm{mM}$ EDTA, $100 \mu \mathrm{g} / \mathrm{ml}$ 4-(2-aminoethyl)benzenesulfonyl fluoride, $10 \mu \mathrm{g} / \mathrm{ml}$ aprotinin, $1 \mu \mathrm{g} / \mathrm{ml}$ pepstatin $\mathrm{A}, 0.5 \mu \mathrm{g} / \mathrm{ml}$ leupeptin, $80 \mathrm{mM} \beta$-glycerophosphate, $25 \mathrm{mM}$ sodium fluoride and $1 \mathrm{mM}$ sodium orthovanadate for $30 \mathrm{~min}$ at $4^{\circ} \mathrm{C}$. Cell lysates were clarified at $12,500 \times \mathrm{g}$ for $20 \mathrm{~min}$ at $4^{\circ} \mathrm{C}$ and the supernatants were subjected to western blot analysis as described previously (36-38). All western blot analyses are representative of at least three independent experiments. Bands of interest were integrated and quantified by the use of National Institutes of Health (NIH) ImageJ version 1.34s software.

Invasion assay. The upper side of the Transwell insert (Costar, 6.5-mm diameterinsert, $8-\mu \mathrm{m}$ pore size) (Corning Inc., Corning, $\mathrm{NY}$, USA) was coated with $50 \mu \mathrm{l}$ of $1 \mathrm{mg} / \mathrm{ml}$ Matrigel ${ }^{\circledR}$ basement membrane matrix $(10.4 \mathrm{mg} / \mathrm{ml}$; BD Biosciences $)$ diluted in EBM-2. Aliquots $(100 \mu \mathrm{l})$ of HUVECs $\left(5 \times 10^{4}\right.$ cells $\left./ \mathrm{ml}\right)$ resuspended in EBM-2 were added to the upper compartment of the Matrigel-coated Transwell and $600 \mu \mathrm{l}$ of EBM-2 was added to the lower compartment. After serum starvation with EBM-2 for $2 \mathrm{~h}$, cells were incubated for $18 \mathrm{~h}$ in EGM-2 BulletKit media in the presence or absence of LF ( 1 and $10 \mu \mathrm{g} / \mathrm{ml})$. The inserts were fixed with methanol and using a cotton-tipped swab the non-invasive cells were removed from the top of the membrane. After staining with $0.04 \%$ Giemsa solution (Sigma-Aldrich, St. Louis, MO, USA), the number of invasive cells was determined from six different fields using x 200 objective magnification.

Tube formation assay. Each well of pre-chilled 24-well plates was coated with $200 \mu$ l Matrigel (BD Biosciences). Following serum starvation with EBM-2 for $2 \mathrm{~h}$, HUVECs $\left(3 \times 10^{4}\right.$ cells $\left./ \mathrm{ml}\right)$ were added to Matrigel ${ }^{\circledR}$-coated plates and incubated for $6 \mathrm{~h}$ in EGM-2 BulletKit media in the presence or absence of LF (1 and $10 \mu \mathrm{g} / \mathrm{ml})$. Tube formation was observed with an Olympus CKX41 inverted microscope (CAchN 10/0.25php objective) and ToupTek Toupview software (version x86, 3.5.563; Hangzhou ToupTek Photonics Co., Zhejiang, China) (39). 

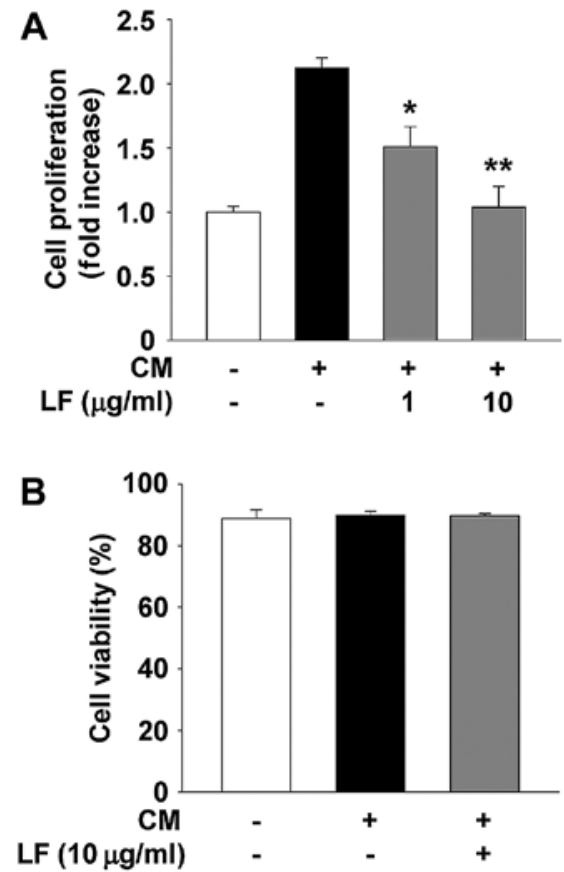

Figure 1. LF inhibits cell proliferation. Cell proliferation and viability were performed as described in Materials and methods. (A) Quiescent HUVECs were incubated for $24 \mathrm{~h}$ in complete media $(\mathrm{CM})$ containing growth factors with or without LF (1 and $10 \mu \mathrm{g} / \mathrm{ml}$ ). Statistical significance is indicated $\left({ }^{*} \mathrm{P}<0.05,{ }^{* * *} \mathrm{P}<0.01\right.$, compared with $\mathrm{CM}$-treated cells). (B) Cells were treated with $\mathrm{LF}(10 \mu \mathrm{g} / \mathrm{ml})$ as described in panel A. The results from triplicate determinations (mean $\pm \mathrm{SD}$ ) are presented as the fold-increase of the untreated controls or the percentage of viable cells of total cell count.

Immunofluorescence microscopy. Quiescent HUVECs on gelatin-coated coverslips in 12-well plates were incubated for 30 min in EGM-2 BulletKit media in the presence or absence of $\mathrm{LF}(10 \mu \mathrm{g} / \mathrm{ml})$, fixed with $3.7 \%$ paraformaldehyde for $5 \mathrm{~min}$, washed with PBS, permeabilized with $0.1 \%$ Triton X-100 for 10 min, washed with PBS and blocked with PBS containing 5\% BSA for $1 \mathrm{~h}$. Primary antibodies diluted 1:100 in 5\% BSA-PBS were incubated for $2 \mathrm{~h}$ at room temperature, washed with PBS, and followed by Alexa Fluor 488-conjugated goat anti-mouse IgG (Life Technologies, Grand Island, NY, USA). Images were obtained with Carl Zeiss microscope (Axio Imager. M2) and AxioVision Rel. 4.8 software (Zeiss Co., Gottingen, Germany).

Statistical analysis. Statistical analysis was performed using the Student's t-test and was based on at least three different experiments. The results were considered to be statistically significant at $\mathrm{P}<0.05$.

\section{Results}

LF suppresses endothelial cell proliferation through regulating the expression of cell cycle-related proteins. We first examined the ability of LF to modulate cell proliferation of HUVECs. LF treatment suppressed endothelial cell proliferation in a dose-dependent manner (Fig. 1A) and did not alter cell viability (Fig. 1B), indicating that LF inhibition of endothelial cell proliferation is not mediated by induction of apoptosis or cytotoxicity. This finding is similar to the patterns of LF in other cell types as previously reported $(32,33)$. We next examined the effect of LF on the cell cycle by DNA content analysis (Fig. 2A). LF treatment prevented the increase in $\mathrm{S}$ phase (10.2 vs. $8.7 \%$ ) and $\mathrm{G}_{2} / \mathrm{M}$ phase (26.0 vs. $\left.21.5 \%\right)$ and the decrease in $\mathrm{G}_{1}$ phase ( 63.8 vs. $69.8 \%$ ) associated with mitogenic stimulation, similar to those of untreated controls. These observations suggest that $\mathrm{LF}$ inhibits the transition from $\mathrm{G}_{1}$ to $S$ phase, leading to $G_{1}$ arrest, which is well correlated with inhibition of cell proliferation (Fig. 1A). We have previously
A
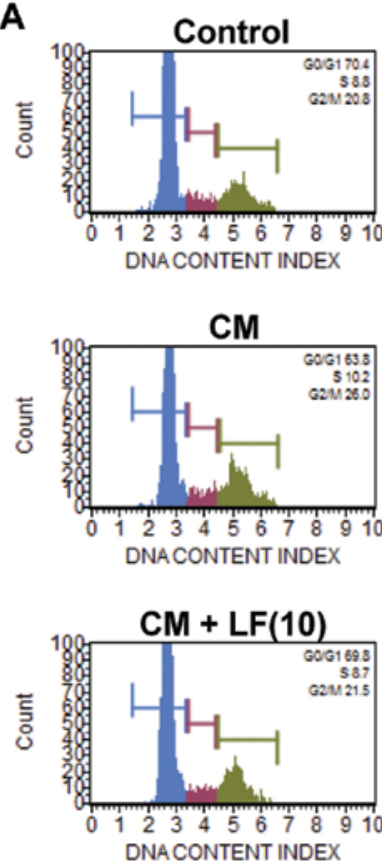

B

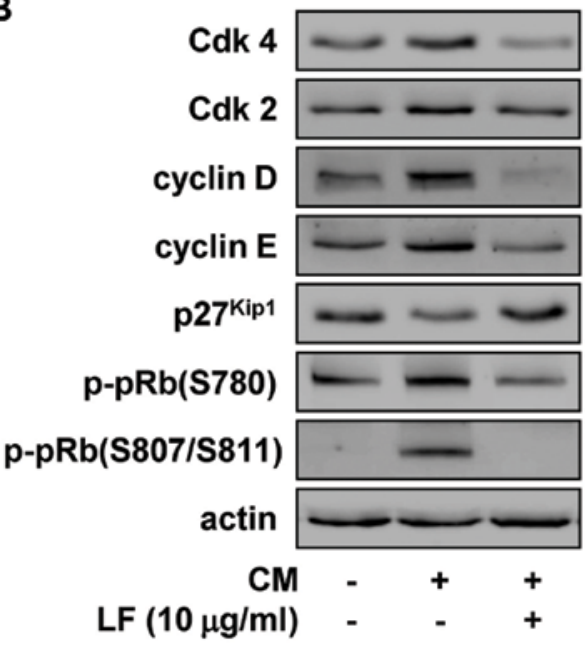

Figure 2. LF modulates cell cycle progression. (A) Cell cycle and (B) Western blot analysis were performed as described in Materials and methods. Quiescent HUVECs were incubated for $24 \mathrm{~h}$ in CM with or without LF $(10 \mu \mathrm{g} / \mathrm{ml})$. Results shown are representative of at least three independent experiments. 

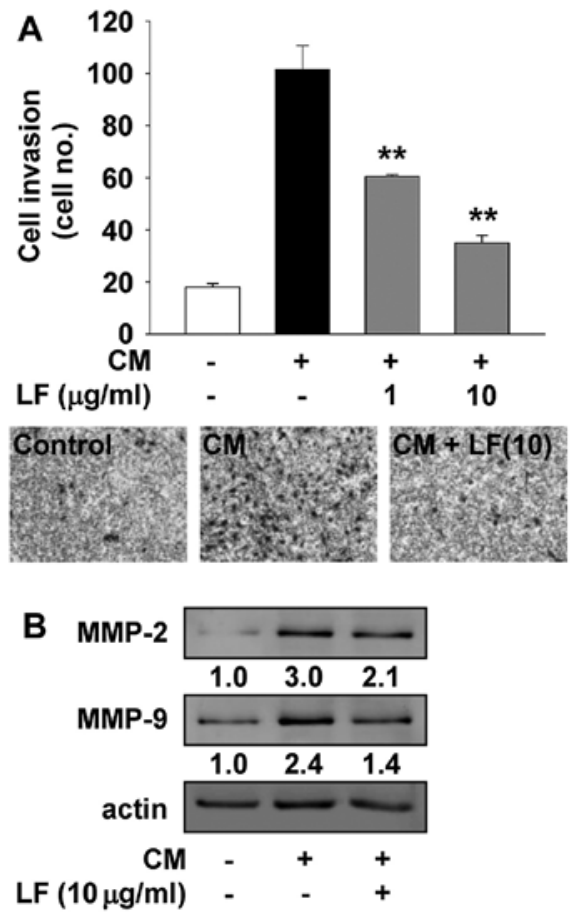

Figure 3. LF inhibits cell invasion. (A) In vitro Transwell invasion was performed as described in Materials and methods. Cells were incubated for $18 \mathrm{~h}$ in CM with or without LF ( 1 and $10 \mu \mathrm{g} / \mathrm{ml})$. Number of invasive cells was determined by counting six different fields of cells (magnification, x200) Results from six independent experiments (mean \pm SD) are presented as the number of invasive cells. Statistical significance is indicated $\left({ }^{* *} \mathrm{P}<0.01\right.$, compared with CM-treated cells). (B) Cells were treated with LF $(10 \mu \mathrm{g} / \mathrm{ml})$ for $24 \mathrm{~h}$ as described in panel A. Cell lysates were western-blotted with anti-MMP-2, anti-MMP-9 or anti-actin antibodies. Integrated density values were normalized to untreated controls. Results shown are representative of at least three independent experiments.

reported that the ethanolic extract and ethyl caffeate, a natural phenolic compound isolated from LF, had growth-suppressive activity in different types of cancer cells including non-small cell lung and ovarian cancer, this inhibitory effect was found to be mediated by downregulation of Cdks and cyclins $(32,33)$. Based on these findings, we analyzed the changes of cell cycle-related proteins such as Cdks, cyclins and Cdk inhibitor p2 $7^{\mathrm{Kip} 1}$ in LF-treated HUVECs. As shown in Fig. 2B, LF treatment markedly reduced the expression of Cdks and cyclins, enhanced the levels of $\mathrm{p} 27^{\mathrm{Kip} 1}$, leading to inhibition of $\mathrm{pRb}$ phosphorylation in response to mitogenic stimulation. These findings clearly show the regulatory effects of LF on cell cycle progression and proliferation in HUVECs.

LF inhibits endothelial cell invasion and tube formation. The release of a variety of biologically active molecules from ECM and cell surface components by MMP-mediated proteolytic degradation is associated with the regulation of cellular behavior such as cell adhesion, migration and invasion (6-8). Thus, we next examined the changes of cell invasion and MMP expression in LF-treated HUVECs. As shown in Fig. 3, LF treatment markedly inhibited the invasion and MMP expression in response to mitogenic stimuli, suggesting that the anti-invasive activity of LF may be mediated through downregulation of MMP expression. In addition, LF treatment completely suppressed mitogen-induced capillary-like structure formation to the levels observed in untreated controls (Fig. 4). Collectively, these findings clearly show the pharmacological roles of LF in regulating endothelial cell proliferation, invasion and tube formation.

Anti-angiogenic effects of LF are mediated through the downregulation of mitogenic signaling pathways and VE-cadherin expression. Distribution of VE-cadherin at cell-cell contacts has been reported to enhance the stability of adherens junctions, resulting in maintenance of endothelial barrier function $(9,10)$. Angiogenic factors such as VEGF-A disrupt the loss of VE-cadherin from the endothelial cell surfaces and induces endothelial cell responses such as permeability, proliferation, invasion and tube formation $(13,14)$. Change of VE-cadherin function can be assessed by the levels of VE-cadherin detectable at cell-cell contacts. As shown in Fig. 5A, LF treatment prevented the mitogen-induced loss of VE-cadherin from cell-cell contacts, similar to untreated controls. To further investigate the molecular mechanisms by which LF modulates mitogen-induced endothelial cell responses, we examined
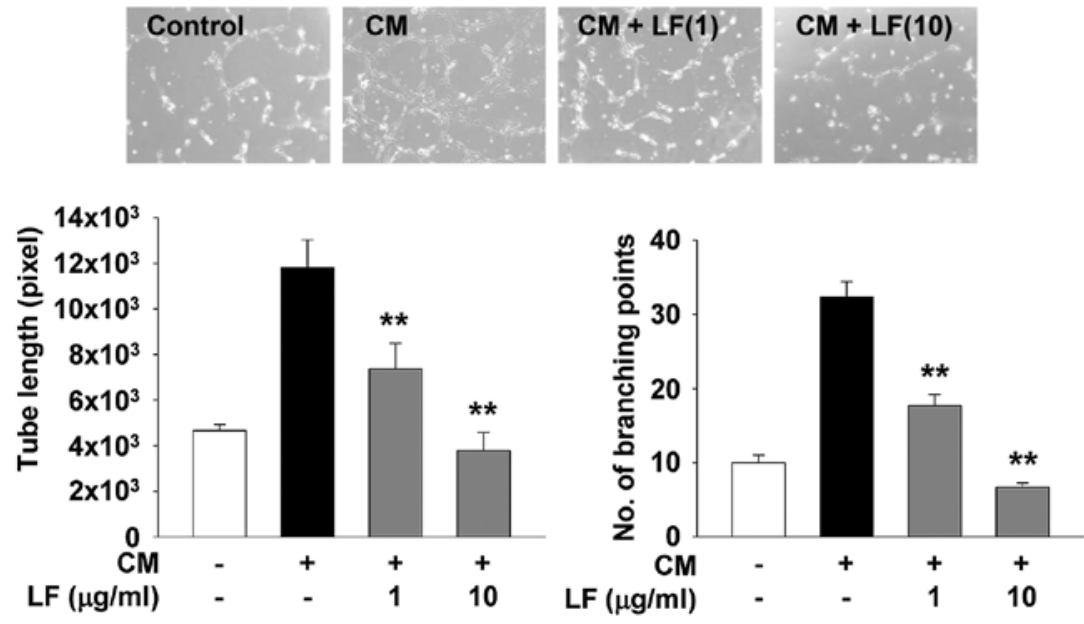

Figure 4. LF inhibits capillary-like structure formation. Tube formation was performed as described in Materials and methods, and quantified by measuring the length of tubes and number of branching points per unit area. Cells were incubated for $6 \mathrm{~h}$ in CM with or without LF (1 and $10 \mu \mathrm{g} / \mathrm{ml})$. Statistical significance is indicated ( ${ }^{* *} \mathrm{P}<0.01$, compared with $\mathrm{CM}$-treated cells). 
A

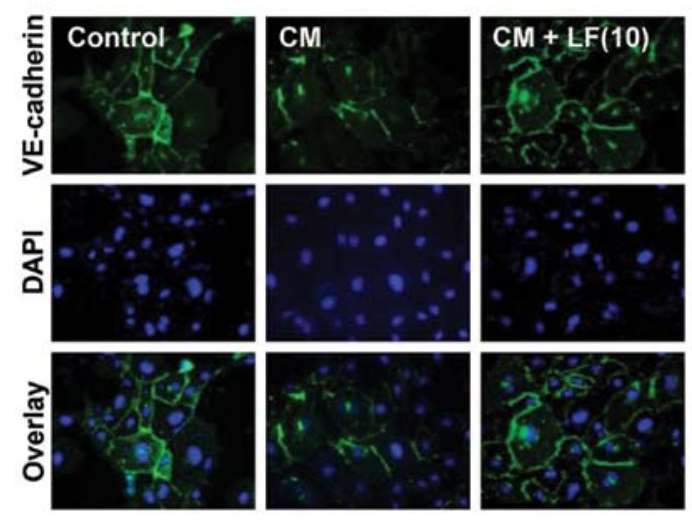

B

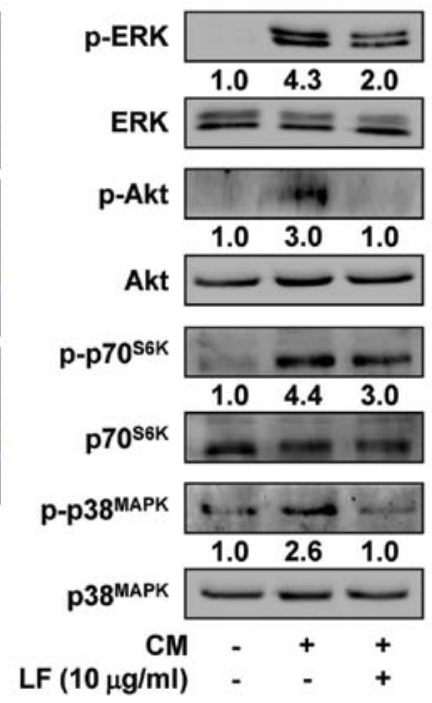

Figure 5. LF inhibits mitogenic signaling pathways and induces the localization of VE-cadherin at cell-cell contacts. (A) Cells were incubated for 30 min in $\mathrm{CM}$ with or without LF $(10 \mu \mathrm{g} / \mathrm{ml})$. DNA was stained with 4,6-diamidino-2-phenylindole (DAPI). (B) Cells were treated with LF (10 $\mu \mathrm{g} / \mathrm{ml})$ for $15 \mathrm{~min}$ as described in panel A. Cell lysates were western-blotted with anti-phospho-ERK, anti-ERK, anti-phospho-Akt, anti-Akt, anti-phospho-p70 ${ }^{\text {S6K }}$, anti-p70 ${ }^{\text {S6K }}$, anti-phospho-p38 $8^{\mathrm{MAPK}}$ or anti-p38 $8^{\mathrm{MAPK}}$ antibodies. Integrated density values were normalized to untreated controls. Results shown are representative of at least three independent experiments.

the changes in activation of mitogenic signaling pathways including ERK, Akt, p70 ${ }^{\mathrm{S} 6 \mathrm{~K}}$ and $\mathrm{p} 38^{\mathrm{MAPK}}$ (40). As shown in Fig. 5B, LF treatment markedly inhibited the mitogen-induced phosphorylation/activation of ERK, Akt, p70 ${ }^{\mathrm{S} 6 \mathrm{~K}}$ and $\mathrm{p} 38^{\mathrm{MAPK}}$ in HUVECs. Collectively, these observations suggest that anti-angiogenic activities of LF may be mediated at least in part through the inactivation of mitogenic signaling pathways and redistribution of VE-cadherin at cell-cell contacts.

\section{Discussion}

Overexpressed receptor tyrosine kinases (RTKs) and dysregulation of RTK downstream signaling pathways are closely associated with pathological conditions including cancer (40). Selective inhibition or normalization of RTK-mediated signaling pathways has widely been appreciated as a rational therapeutic strategy. However, many drugs that target RTKs and the downstream signaling networks frequently lead to drug resistance and adverse effects in clinical trials or use. Therefore, natural products which act simultaneously on multiple molecular targets can sometimes be of therapeutic benefit in treating diseases. LF has been used for improving liver function, as well as in inflammatory and infectious disorders. These applications of LF may be mediated through anti-inflammatory, anti-oxidative and anti-hepatotoxic effects (25-28). We have previously reported that the ethanolic extract of LF inhibits proliferation and migration of non-small cell lung cancer cells through the inactivation of signaling pathways such as ERK, Akt and p70 ${ }^{\mathrm{S} 6 \mathrm{~K}}$, and the downregulation of epidermal growth factor receptor, integrin $\beta 1$ and integrin-linked kinase (ILK) (32). In addition, ethyl caffeate, a natural phenolic compound isolated from the ethanolic extract of LF, exerts anti-proliferative, anti-migratory and anti-invasive activities in ovarian cancer cells. The mechanism of these effects involves suppression of signaling pathways including ERK, Akt, p70 ${ }^{\mathrm{S} 6 \mathrm{~K}}$ and $\mathrm{p} 38^{\mathrm{MAPK}}$, and downregulation of human epidermal growth factor receptor 2, fibroblast growth factor receptor-1, vascular endothelial growth factor receptor-2, integrin $\alpha 3 \beta 1$, ILK and N-cadherin (33).

In the present study, we demonstrate for the first time that LF inhibits mitogen-induced endothelial cell proliferation, invasion and tube formation. These anti-angiogenic activities of LF were found to be mediated through the inactivation of mitogenic signaling pathways, redistribution of VE-cadherin at cell-cell contacts and downregulation of MMP expression. Based on the regulatory effects of LF on MMP expression, we examined the ability of LF to alter the levels of TIMP-2, an endogenous inhibitor of MMPs which has been known to regulate cell proliferation and differentiation through MMP-dependent and/or MMP-independent mechanism $(15,16,21)$. LF treatment showed little or no change of TIMP-2 expression in mitogen-treated HUVECs (data not shown). These findings indicate that anti-angiogenic effects of LF may be mediated through the regulation of MMP-2 and MMP-9, but not that of TIMP-2. However, it cannot exclude the possibility that LF may modulate the expression and activity of other MMP and TIMP family members.

In conclusion, the present study demonstrates the pharmacological roles and mechanisms of LF in the regulation of angiogenesis, and warrants further evaluation and development of LF for the prevention and treatment of pathological states associated with angiogenesis.

\section{Acknowledgements}

This study was supported by the High Value-added Food Technology Development Program (112060-3) through the Ministry of Agriculture, Food and Rural Affairs, and by the Basic Science Research Program(2010-0021913,2014R1A1A2058015) through the National Research Foundation of Korea, Ministry of Education. 


\section{References}

1. Cristofanilli M, Charnsangavej $\mathrm{C}$ and Hortobagyi GN: Angiogenesis modulation in cancer research: novel clinical approaches. Nat Rev Drug Discov 1: 415-426, 2002.

2. Folkman J: Angiogenesis: an organizing principle for drug discovery? Nat Rev Drug Discov 6: 273-286, 2007.

3. Carmeliet P and Jain RK: Principles and mechanisms of vessel normalization for cancer and other angiogenic diseases. Nat Rev Drug Discov 10: 417-427, 2011.

4. Cook KM and Figg WD: Angiogenesis inhibitors: current strategies and future prospects. CA Cancer J Clin 60: 222-243, 2010.

5. Nyberg P, Xie L and Kalluri R: Endogenous inhibitors of angiogenesis. Cancer Res 65: 3967-3979, 2005.

6. Stetler-Stevenson WG: Matrix metalloproteinases in angiogenesis: a moving target for therapeutic intervention. J Clin Invest 103: 1237-1241, 1999.

7. Kessenbrock K, Plaks V and Werb Z: Matrix metalloproteinases: regulators of the tumor microenvironment. Cell 141: 52-67, 2010

8. Bourboulia D and Stetler-Stevenson WG: Matrix metalloproteinases (MMPs) and tissue inhibitors of metalloproteinases (TIMPs): positive and negative regulators in tumor cell adhesion. Semin Cancer Biol 20: 161-168, 2010.

9. Dejana E, Orsenigo F and Lampugnani MG: The role of adherens junctions and VE-cadherin in the control of vascular permeability. J Cell Sci 121: 2115-2122, 2008.

10. Kim SH, Cho YR, Kim HJ, Oh JS, Ahn EK, Ko HJ, Hwang BJ, Lee SJ, Cho Y, Kim YK, et al: Antagonism of VEGF-A-induced increase in vascular permeability by an integrin a331-Shp-1-cAMP/PKA pathway. Blood 120: 4892-4902, 2012.

11. Herren B, Levkau B, Raines EW and Ross R: Cleavage of beta-catenin and plakoglobin and shedding of VE-cadherin during endothelial apoptosis: evidence for a role for caspases and metalloproteinases. Mol Biol Cell 9: 1589-1601, 1998.

12. Grazia Lampugnani M, Zanetti A, Corada M, Takahashi T, Balconi G, Breviario F, Orsenigo F, Cattelino A, Kemler R, Daniel TO, et al: Contact inhibition of VEGF-induced proliferation requires vascular endothelial cadherin, beta-catenin, and the phosphatase DEP-1/CD148. J Cell Biol 161: 793-804, 2003.

13. George SJ and Dwivedi A: MMPs, cadherins, and cell proliferation. Trends Cardiovasc Med 14: 100-105, 2004.

14. Spring K, Chabot C, Langlois S, Lapointe L, Trinh NT, Caron C, Hebda JK, Gavard J, Elchebly M and Royal I: Tyrosine phosphorylation of DEP-1/CD148 as a mechanism controlling Src kinase activation, endothelial cell permeability, invasion, and capillary formation. Blood 120: 2745-2756, 2012.

15. Brew $\mathrm{K}$ and Nagase $\mathrm{H}$ : The tissue inhibitors of metalloproteinases (TIMPs): an ancient family with structural and functional diversity. Biochim Biophys Acta 1803: 55-71, 2010.

16. Seo D-W, Li H, Guedez L, Wingfield PT, Diaz T, Salloum R, Wei BY and Stetler-Stevenson WG: TIMP-2 mediated inhibition of angiogenesis: an MMP-independent mechanism. Cell 114: 171-180, 2003

17. Qi JH, Ebrahem Q, Moore N, Murphy G, Claesson-Welsh L, Bond M, Baker A and Anand-Apte B: A novel function for tissue inhibitor of metalloproteinases-3 (TIMP3): inhibition of angiogenesis by blockage of VEGF binding to VEGF receptor-2. Nat Med 9: 407-415, 2003.

18. Jung KK, Liu XW, Chirco R, Fridman R and Kim HR: Identification of CD63 as a tissue inhibitor of metalloproteinase-1 interacting cell surface protein. EMBO J 25: 3934-3942, 2006.

19. Seo DW, Li H, Qu CK, Oh J, Kim YS, Diaz T, Wei B, Han JW and Stetler-Stevenson WG: Shp-1 mediates the antiproliferative activity of tissue inhibitor of metalloproteinase- 2 in human microvascular endothelial cells. J Biol Chem 281: 3711-3721, 2006

20. Seo DW, Kim SH, Eom SH, Yoon HJ, Cho YR, Kim PH, Kim YK, Han JW, Diaz T, Wei BY, et al: TIMP-2 disrupts FGF-2-induced downstream signaling pathways. Microvasc Res 76: 145-151, 2008

21. Stetler-Stevenson WG: Tissue inhibitors of metalloproteinases in cell signaling: metalloproteinase-independent biological activities. Sci Signal 1: re6, 2008.
22. Coussens LM, Fingleton B and Matrisian LM: Matrix metalloproteinase inhibitors and cancer: trials and tribulations. Science 295: 2387-2392, 2002.

23. Vandenbroucke RE and Libert C: Is there new hope for therapeutic matrix metalloproteinase inhibition? Nat Rev Drug Discov 13: 904-927, 2014

24. Hwang BY, Lee JH, Koo TH, Kim HS, Hong YS, Ro JS, Lee KS and Lee JJ: Furanoligularenone, an eremophilane from Ligularia fischeri, inhibits the LPS-induced production of nitric oxide and prostaglandin E2 in macrophage RAW264.7 cells. Planta Med 68: 101-105, 2002.

25. Lee KH and Choi EM: Analgesic and anti-inflammatory effects of Ligularia fischeri leaves in experimental animals. J Ethnopharmacol 120: 103-107, 2008.

26. Choi EM: Ligularia fischeri leaf extract prevents the oxidative stress in DBA/1J mice with type II collagen-induced arthritis. J Appl Toxicol 27: 176-182, 2007.

27. Shang YF, Kim SM, Song DG, Pan CH, Lee WJ and Um BH: Isolation and identification of antioxidant compounds from Ligularia fischeri. J Food Sci 75: C530-C535, 2010.

28. Choi J, Park JK, Lee KT, Park KK, Kim WB, Lee JH, Jung HJ and Park HJ: In vivo antihepatotoxic effects of Ligularia fischeri var. spiciformis and the identification of the active component, 3,4-dicaffeoylquinic acid. J Med Food 8: 348-352, 2005

29. Cha KH, Song DG, Kim SM and Pan CH: Inhibition of gastrointestinal lipolysis by green tea, coffee, and gomchui (Ligularia fischeri) tea polyphenols during simulated digestion. J Agric Food Chem 60: 7152-7157, 2012

30. Jeong SH, Koo SJ, Choi JH, Park JH, Ha J, Park HJ and Lee KT: Intermedeol isolated from the leaves of Ligularia fischeri var. spiciformis induces the differentiation of human acute promyeocytic leukemia HL-60 cells. Planta Med 68: 881-885, 2002.

31. Xie WD, Li X, Weng CW, Liu SS and Row KH: Fischerisin A and $\mathrm{B}$, cytotoxic sesquiterpenoid-geranylhydroquinones from Ligularia fischeri. Chem Pharm Bull (Tokyo) 59: 511-514, 2011.

32. Cho YR, Kim JK, Kim J, Oh J and Seo DW: Ligularia fischeri regulates lung cancer cell proliferation and migration through down-regulation of epidermal growth factor receptor and integrin $\beta 1$ expression. Genes Genom 35: 741-746, 2013

33. Lee HN, Kim JK, Kim JH, Lee SJ, Ahn EK, Oh JS and Seo DW A mechanistic study on the anti-cancer activity of ethyl caffeate in human ovarian cancer SKOV-3 cells. Chem Biol Interact 219: 151-158, 2014.

34. Kim HJ, Cho YR, Kim SH and Seo DW: TIMP-2-derived 18-mer peptide inhibits endothelial cell proliferation and migration through cAMP/PKA-dependent mechanism. Cancer Lett 343: 210-216, 2014.

35. Kim HJ, Ko HY, Choi SW and Seo DW: Anti-angiogenic effects of Siegesbeckia glabrescens are mediated by suppression of the Akt and $\mathrm{p} 70^{\mathrm{S} 6 \mathrm{~K}}$-dependent signaling pathways. Oncol Rep 33: 699-704, 2015.

36. Cho YR, Choi SW and Seo DW: The in vitro antitumor activity of Siegesbeckia glabrescens against ovarian cancer through suppression of receptor tyrosine kinase expression and the signaling pathways. Oncol Rep 30: 221-226, 2013.

37. Lee HN, Joo JH, Oh JS, Choi SW and Seo DW: Regulatory effects of Siegesbeckia glabrescens on non-small cell lung cancer cell proliferation and invasion. Am J Chin Med 42: 453-463, 2014.

38. Yoon HJ, Cho YR, Joo JH and Seo DW: Knockdown of integrin $\alpha 3 \beta 1$ expression induces proliferation and migration of non-small cell lung cancer cells. Oncol Rep 29: 662-668, 2013.

39. Cho YR, Kim JH, Kim JK, Ahn EK, Ko HJ, In JK, Lee SJ, Bae GU, Kim YK, Oh JS, et al: Broussonetia kazinoki modulates the expression of VEGFR-2 and MMP-2 through the inhibition of ERK, Akt and p70 $0^{\mathrm{S} 6 \mathrm{~K}}$-dependent signaling pathways: its implication in endothelial cell proliferation, migration and tubular formation. Oncol Rep 32: 1531-1536, 2014.

40. Lemmon MA and Schlessinger J: Cell signaling by receptor tyrosine kinases. Cell 141: 1117-1134, 2010. 